\title{
Effect of Emission Penalty and Annual Interest Rate on Cogeneration of Electricity, Heat, and Hydrogen in Karachi: 3E Assessment and Sensitivity Analysis
}

\author{
Mehdi Jahangiri (D), ${ }^{1}$ Ali Mostafaeipour ${ }^{1 D},{ }^{2,3,4}$ Habib Ur Rahman Habib ${ }^{(D},{ }^{5}$ \\ Hamed Saghaei $\mathbb{D}^{6}{ }^{6}$ and Asad Waqar ${ }^{7}$ \\ ${ }^{1}$ Department of Mechanical Engineering, Shahrekord Branch, Islamic Azad University, Shahrekord, Iran \\ ${ }^{2}$ Industrial Engineering Department, Yazd University, Yazd, Iran \\ ${ }^{3}$ Faculty Environmental Management, Prince of Songkla University, 90110 Songkhla, Thailand \\ ${ }^{4}$ Environmental Assessment and Technology for Hazardous Waste Management Research Center, \\ Faculty of Environmental Management, Prince of Songkla University, 90110 Songkhla, Thailand \\ ${ }^{5}$ Department of Electrical Engineering, Faculty of Electrical and Electronics Engineering, \\ University of Engineering and Technology Taxila, Taxila 47050, Pakistan \\ ${ }^{6}$ Department of Electrical Engineering, Shahrekord Branch, Islamic Azad University, Shahrekord, Iran \\ ${ }^{7}$ Department of Electrical Engineering, Bahria University, 44000 Islamabad, Pakistan
}

Correspondence should be addressed to Mehdi Jahangiri; jahangiri.m@iaushk.ac.ir

Received 17 December 2020; Accepted 12 April 2021; Published 28 April 2021

Academic Editor: Amiya K. Jana

Copyright $\odot 2021$ Mehdi Jahangiri et al. This is an open access article distributed under the Creative Commons Attribution License, which permits unrestricted use, distribution, and reproduction in any medium, provided the original work is properly cited.

\begin{abstract}
Pakistan is the world's sixth-most populous country with a semi-industrialized economy. It has been always an energy importer and dependent on fossil fuels. Great pressure is imposed on Pakistan's national grid from the rise in fossil fuel costs, variations in the annual interest rate, and increased costs of greenhouse emissions. To meet the ever-increasing energy demand, the Government of Pakistan has decided to further harness wind and solar energies currently having a negligible share in Pakistan's energy portfolio. Despite the importance of this issue, no study has been conducted so far on the cogeneration of power, heat, and hydrogen in Pakistan. Accordingly, this study is aimed at technical-economic-environmental sensitivity analysis of supplying electric and thermal loads of a residential building in Karachi by an off-grid wind-solar-fuel cell system. To this end, 4500000 possible cases were analyzed, simulated, and optimized with the HOMER software using 20-year average meteorological data from the NASA website. A sensitivity analysis was performed on this system for the first time in Pakistan. The other novelties are the use of dump loads for converting the surplus electricity into heat and also heat recovering in the fuel cells. The results showed the great potential of the station understudy for supplying the required power and heat by renewable energies. Hydrogen production was also affordable at every emission penalty price with an interest rate of less than $9 \%$. Moreover, dump loads play a key role in supplying the thermal demand. Comparison of the wind turbine-solar cell-fuel cell-battery system with the wind turbine-solar cell-battery and solar cell-battery systems indicated that the internal rate of return and the payback period were, respectively, $9.39 \%$ and 11.4 years and $11.7 \%$ and 11 years. According to these results, it is recommend that Pakistani authorities promote the use of renewable energies through incentives and investment subsidies.
\end{abstract}

\section{Introduction}

Energy has been turned into a necessity for improving the quality of life and income in developing countries such as Pakistan [1] leading to a growing demand for the electric power
[2]. It is noteworthy that sustainable power supply is a perquisite for sustainable economic growth [3-5]. Renewable energies, in particular wind and solar energies, are used for this purpose [6].

Despite a very high potential for renewable energies [7-9], Pakistan has failed to utilize them effectively due to 
inefficient strategies. As shown in Figure 1, Pakistan has failed to compensate over the $500 \mathrm{MW}$ deficit [10] and inaccessibility of about 144 million Pakistanis to the electric power [11] in recent years.

As clearly shown in Figure 2, the share of renewable energies in Pakistan's energy portfolio is only 3\%, which is negligible in comparison with fossil fuels $[12,13]$.

According to the reports, Pakistan's estimated wind energy potential is $346 \mathrm{GW}$ [2]. Of this, $308 \mathrm{MW}$ is currently in operation and $1140 \mathrm{MW}$ is under construction [4]. As shown in Figure 3 [14], the Sindh coastal line and Baluchistan are the most susceptible areas for the use of wind energy in Pakistan. Of $43 \mathrm{GW}$ wind energy capacity in these regions, only $11 \mathrm{GW}$ can be commercially utilized $[15,16]$.

The high investment cost is the main factor preventing the development of wind energy in Pakistan [2]. The high noise of large wind turbines and damages to birds are other negative features in this regard [17]. Accordingly, it is recommended to use home-scale wind turbines not having these problems.

Geographically, Pakistan is located in a region with a high solar radiation potential so that $95 \%$ of its territory receives an average daily solar radiation of $5-7 \mathrm{kWh} / \mathrm{m}^{2}$ [18]. According to Figure 4 [19], most desert regions in Baluchistan, Sindh, and Punjab have the highest solar energy potential in Pakistan [20]. Of the estimated solar energy potential of 2.9 TW in Pakistan [21,22], 100 MW is currently in operation and $856 \mathrm{MW}$ is under construction [4].

Given the great public interest in solar cells, particularly for partial loads [23], it is recommended to use a hybrid solar cell-small wind turbine system to generate more sustainable energy by eliminating the drawbacks of solar cells and wind turbines [24].

Hydrogen can play a key role in improving energy security and reducing greenhouse emissions in Pakistan $[25,26]$. Hydrogen generated from a renewable resource could be a clean sustainable fuel $[27,28]$; wind and solar energies are the most reliable renewable resources in this field in Pakistan [25, 29]. Despite the considerable growth of global hydrogen generation, unfortunately, hydrogen has no share in Pakistan's energy portfolio [25]. Given few studies on hydrogen generation from renewable energies in Pakistan, it is recommended to consider hydrogen production from wind and solar energies. Table 1 summarizes recent technical-economic-environmental feasibility studies on renewable energies in Pakistan.

Figure 5 shows electric power consumption in different sectors in Pakistan [8]. As seen, the domestic sector is the major consumer of electric power in Pakistan [4]; thus the electric power supply for a residential building was considered in this study. Moreover, Pakistan is largely dependent on thermal energy so $35 \%$ of the electric power is consumed for heat generation [6]. According to the literature, there is no technical-economic-environmental feasibility study on the cogeneration of power, heat, and hydrogen in Pakistan. For the first time in this study, the effect of emission penalties and the annual interest rate was studied on the performance of a renewable hybrid system for cogeneration of power, heat, and hydrogen using NASA's 20 -year average meteoroidal data

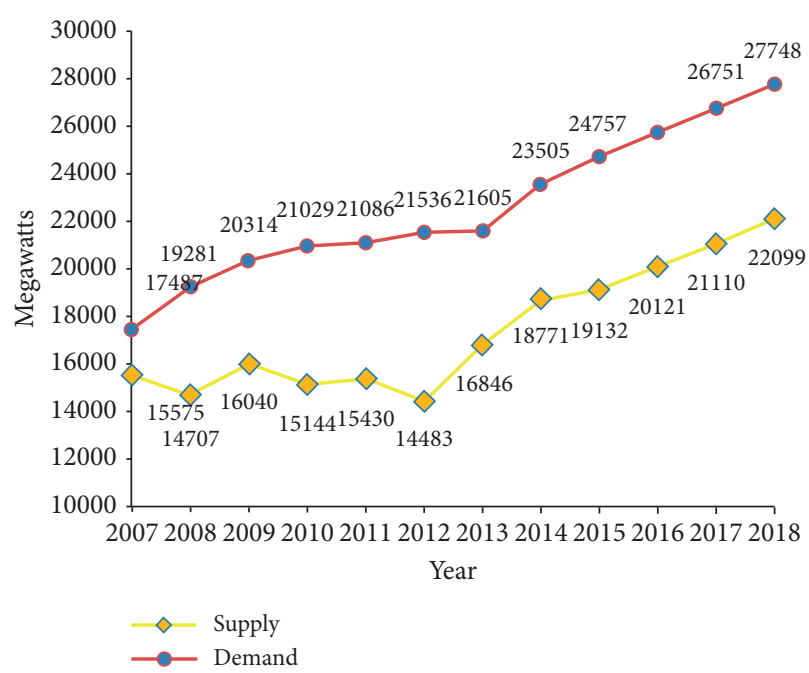

Figure 1: Electric power demand and supply in Pakistan [10].

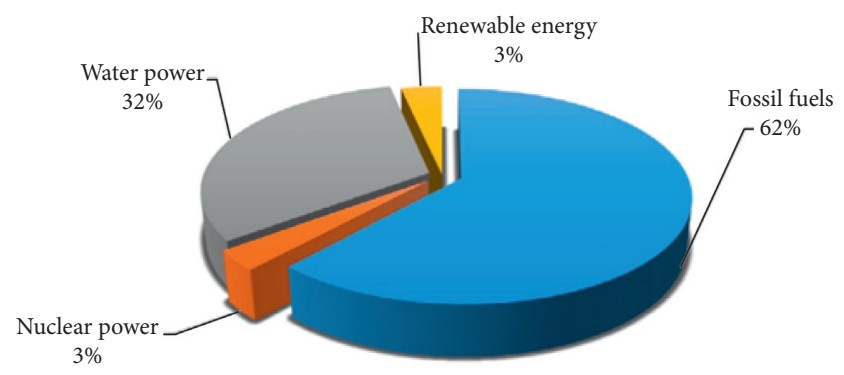

FIgURE 2: The production capacity per energy source $[12,13]$.

[41] with the HOMER software. The results of this study will be not only helpful for the utilization of hybrid renewable energies in Pakistan but also useful for other countries with the same climate aiming at implementing similar projects in the future.

\section{Study Area}

Pakistan with the capital city Islamabad is located in South Asia. Pakistan has a $1000 \mathrm{~km}$ maritime boundary with the Oman Sea in the south and is neighbor to Iran from the west, Afghanistan from the north, India from the east, and China from the northeast. With a land area of $796096 \mathrm{~km}^{2}$, Pakistan is located on the global solar belt [4]. About $95 \%$ of Pakistan's land is exposed to solar radiation in over 300 days for 8-10 h per day [42]. Moreover, $1100 \mathrm{~km}$ of Pakistan's coastal line with a wind speed of $7-8 \mathrm{~m} / \mathrm{s}$ provides a high potential for utilization of wind energy $[43,44]$.

Karachi, the largest city in Pakistan, is the capital city of Sindh Province. As shown in Figures 6 and 7, Karachi is located in the southeast of Pakistan along the Arabian Sea and the northwest of the Sindh Delta. According to the statistics published in 2017, Karachi's population was 14910352. In this regard, Karachi is the most populous city in Pakistan and the sixth-most populous city in the World. Figures 6 and 7, respectively, display the wind speed at an elevation of $100 \mathrm{~m}$ and power generation by solar cells (in 


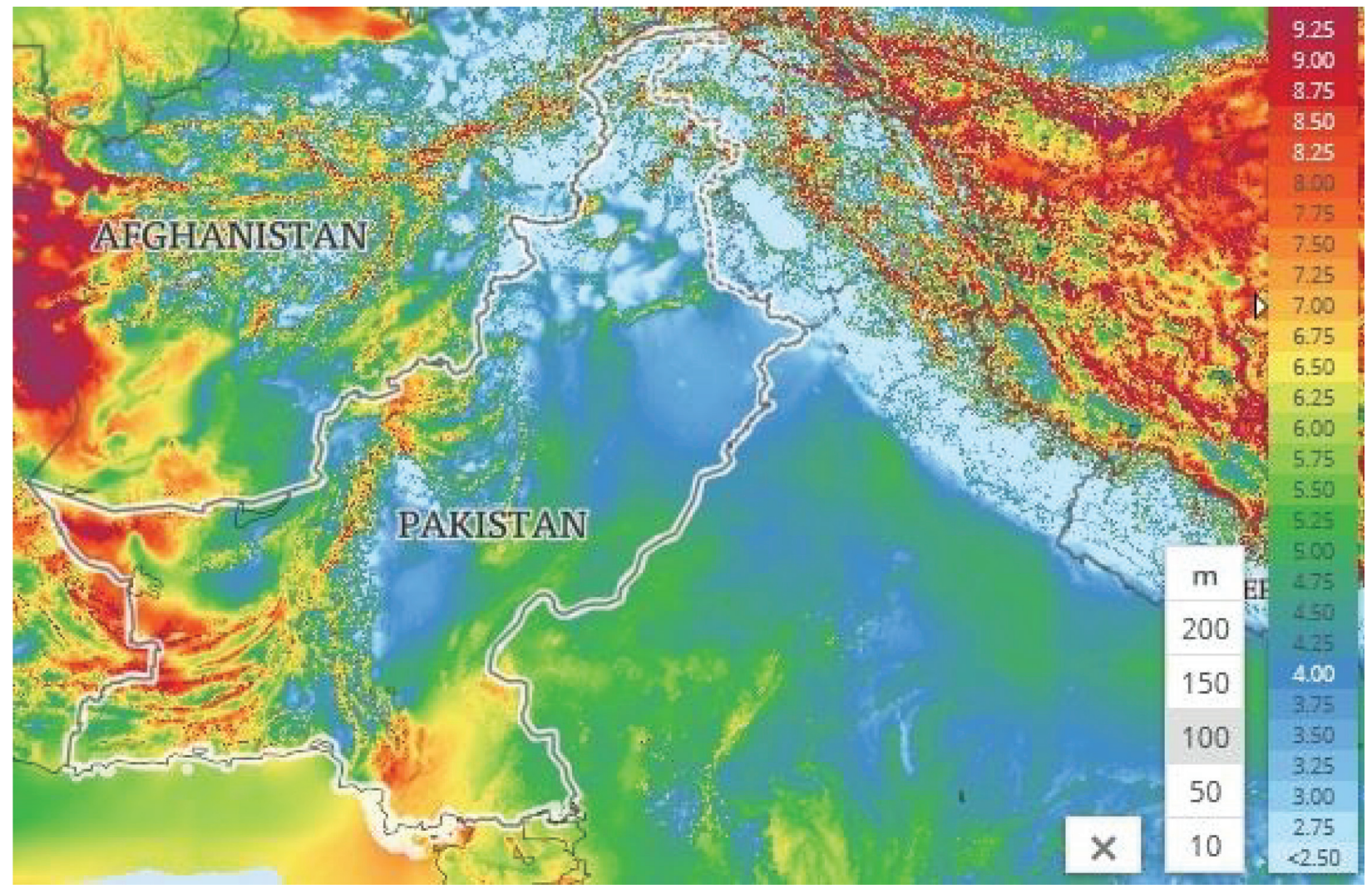

Figure 3: Atlas of wind speed at an elevation of $100 \mathrm{~m}$ [14].

terms of $\mathrm{kWh}$ ). The geographical locations of large wind and solar power plants are also shown in these figures.

The share of renewable energies (except for large hydro) in Pakistan is expected to reach 9700 MW by 2030, seeming achievable considering available potentials and financial and political commitments of the Government of Pakistani in this regard [46].

The above discussion reveals the high solar and wind energy potentials in Karachi and also the ever-increasing need of this megacity for a sustainable energy resource. Accordingly, Karachi was selected as the station investigated in this study.

Although the present work is a case study for Karachi, the new trigeneration system (electricity, heat, and hydrogen) with heat recovery and dump load, as well as the proposed method for analysis and calculation and how to compare the performance of different configurations, in any place of the world can be used.

\section{Difficulties of Wind-Solar System Operation}

One of the problems that producers and consumers of renewable energy face when installing solar cells or wind turbines is finding the right place $[47,48]$. In the case of solar cells, the holder base must be such that it is not damaged by wind. Also, finding the optimal installation angle and cleaning dust from the panels are things that, if properly done, will lead to better solar cell performance [49]. Also, the installation of solar cells should be such that the ventilation behind them is well done [49]. The issue of land prices is also an important issue for the installation site of the solar power plant [50]. Regarding the installation and operation of wind turbines, how to install wind turbines at height is one of the problems. In addition, maintenance is difficult due to the lack of easy access to rotating equipment of wind turbine. Noise pollution and bird damage are also problems that wind turbine users face [51]. Finding the dominant direction of the wind is another problem and exploitation problems $[52,53]$.

\section{Simulation}

4.1. HOMER Software. HOMER developed by the US National Renewable Energy Laboratory (NREL) facilitates the design of off-grid and on-grid systems. The software can be used for simulation, optimization, and sensitivity analysis of energy systems. The result of the analysis is the economic ranking from the minimum to the maximum total net present cost (NPC). HOMER is also used for technical and environmental analysis of systems [54].

The following equation is used in the software to calculate the output power of photovoltaic cells [55]:

$$
P_{\mathrm{pv}}=Y_{\mathrm{pv}} f_{\mathrm{pv}}\left(\frac{\overline{G_{\mathrm{T}}}}{\overline{G_{\mathrm{T} . S T C}}}\right),
$$

where $Y_{\mathrm{pv}}$ represents the output power of the solar cells under standard conditions in terms of $\mathrm{kW}, f_{\mathrm{pv}}$ is the derating factor, $\overline{G_{\mathrm{T}}}$ is the monthly solar irradiation incident on the 


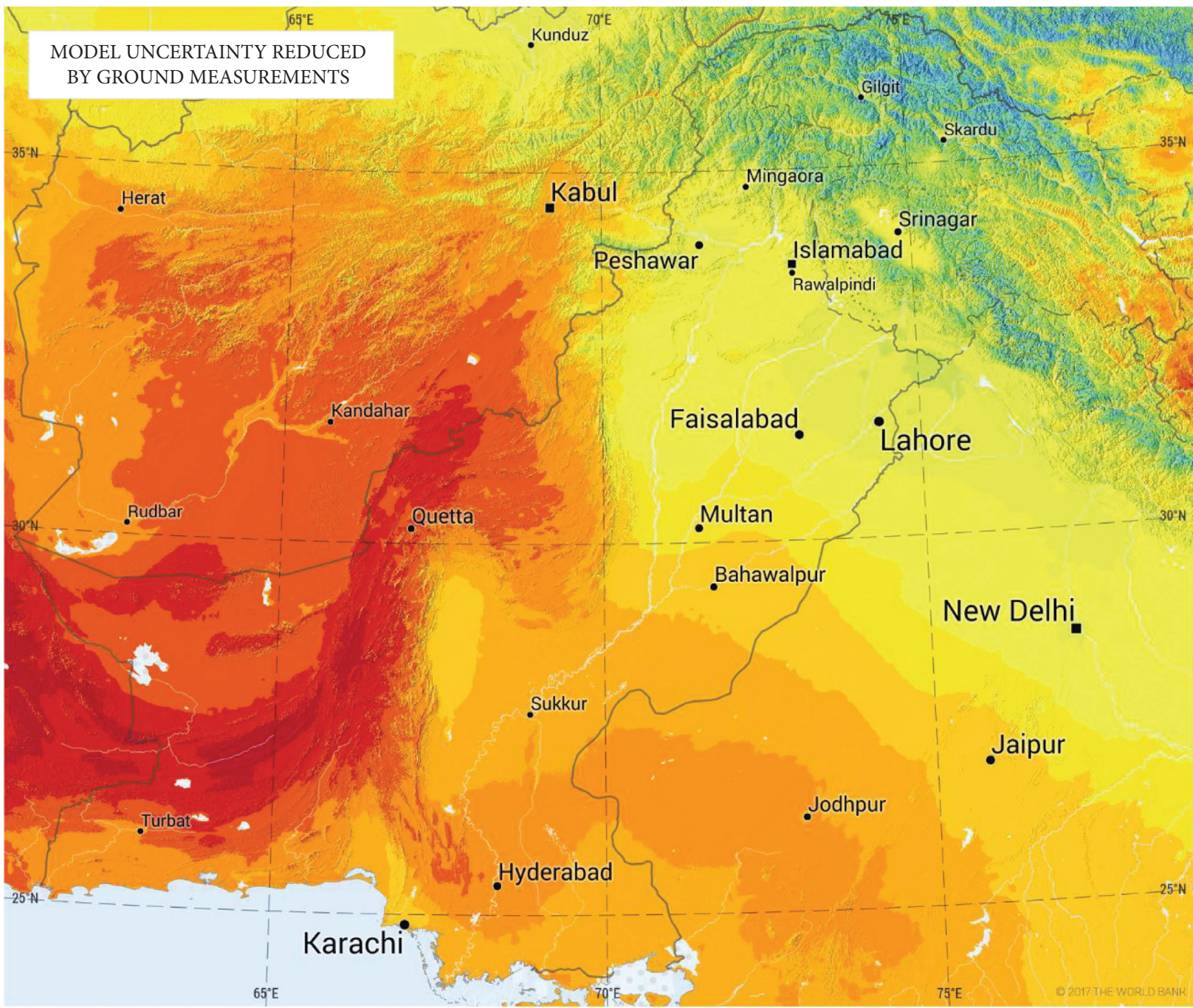

Long-term average of daily/yearly sum, period 1999-2016

\begin{tabular}{ccccccccc} 
Daily sum: & $<3.6$ & 4.0 & 4.4 & 4.8 & 5.2 & 5.6 & 6.0 & $6.4>$ \\
\hline Yearly sum: & $<1314$ & 1461 & 1607 & 1753 & 1899 & 2045 & 2191 & $2337>$
\end{tabular}

$0 \quad 100 \mathrm{~km}$

Figure 4: Atlas of solar radiation in Pakistan [19].

cell surface in terms of $\mathrm{kW} / \mathrm{m}^{2}$, and $\overline{G_{\mathrm{T} . S T C}}$ is the solar irradiation incident on the cell surface under standard conditions in terms of $1 \mathrm{~kW} / \mathrm{m}^{2}$.

Using the power curve and the wind speed at the hub elevation, the output power of wind turbines is calculated as follows [56]:

$$
P_{\mathrm{WTG}}=\frac{\rho}{\rho_{0}} \times P_{\mathrm{WTG} . \mathrm{STP}},
$$

where $\rho$ represents the actual density of air in terms of $\mathrm{kg} /$ $\mathrm{m}^{3}, \rho_{0}$ is the air density at standard temperature, and pressure $\left(\rho_{0}=1.225\right)$ and $P_{\text {WTG.STP }}$ are the output power of wind turbines at standard temperature and pressure.

In each time step, the software calculates the maximum power received by the battery. The maximum power in each time step differs depending on the current state of charge of the battery, discharge history, etc. The software applies three constraints on the maximum charging power of the battery. $P_{\text {batt.cmax.kbm represents the kinetic battery model, }}$ $P_{\text {batt.cmax.mcr }}$ is the maximum charge rate of the battery, and $P_{\text {batt.cmax.mcc }}$ is the maximum charge current. According to (3), the maximum power is considered the minimum of these values [57].

$$
P_{\text {batt.cmax }}=\frac{\operatorname{Min}\left(P_{\text {batt.cmax.kbm }} \cdot P_{\text {batt.cmax.mcr }} \cdot P_{\text {batt.cmax.mcc }}\right)}{\eta_{\text {batt.c }}},
$$

where $\eta_{\text {batt.c }}$ is the charging efficiency of the battery.

By entering the fuel curve for the fuel cell, the software plots the corresponding efficiency curve. Equation (4) represents the electrical efficiency of the fuel cell [58]. 
Table 1: Recent studies on renewable energies in Pakistan.

\begin{tabular}{|c|c|c|c|c|c|c|c|c|c|}
\hline $\begin{array}{l}\text { Ref., } \\
\text { year }\end{array}$ & Station & Load type & Method & $\begin{array}{c}\text { Studied } \\
\text { parameter }\end{array}$ & $\begin{array}{c}\text { Connection } \\
\text { type }\end{array}$ & $\begin{array}{c}\text { Optimum } \\
\text { configuration }\end{array}$ & $\begin{array}{c}\text { Sensitivity } \\
\text { analysis }\end{array}$ & $\begin{array}{c}\text { Dump } \\
\text { load }\end{array}$ & $\begin{array}{c}\text { Emission } \\
\text { penalty }\end{array}$ \\
\hline $\begin{array}{l}{[30],} \\
2017\end{array}$ & Layyah & Electricity & HOMER & Total NPC & Off-grid & $\begin{array}{l}\text { PV cell-biogas } \\
\text { generator-battery }\end{array}$ & No & No & No \\
\hline $\begin{array}{l}{[31],} \\
2018\end{array}$ & Gujranwala & Electricity & HOMER & Total NPC & Off-grid & $\begin{array}{l}\text { PV cell-fuel cell- } \\
\text { diesel generator- } \\
\text { battery }\end{array}$ & No & No & No \\
\hline $\begin{array}{l}{[32],} \\
2018\end{array}$ & Chakwal & Electricity & HOMER & Total NPC & On-grid & $\begin{array}{l}\text { PV cell-wind } \\
\text { turbine-biogas } \\
\text { generator }\end{array}$ & No & No & No \\
\hline $\begin{array}{l}{[33],} \\
2018\end{array}$ & $\begin{array}{l}\text { Four } \\
\text { selected } \\
\text { sites }\end{array}$ & Electricity & Analytical & $\begin{array}{l}\text { Hydrogen } \\
\text { cost }\end{array}$ & Off-grid & Wind turbine & No & No & No \\
\hline $\begin{array}{l}{[34],} \\
2018\end{array}$ & Punjab & Electricity & HOMER & Total NPC & Off-grid & $\begin{array}{l}\text { Hydroturbine-PV } \\
\text { cell-wind turbine- } \\
\text { diesel generator }\end{array}$ & No & No & No \\
\hline$[1], 2019$ & Bhimber & Electricity & HOMER & Total NPC & $\begin{array}{l}\text { On-grid off- } \\
\text { grid }\end{array}$ & $\begin{array}{l}\text { PV cell-diesel } \\
\text { generator PV- } \\
\text { Battery }\end{array}$ & No & No & No \\
\hline $\begin{array}{l}{[35],} \\
2019\end{array}$ & Mohmand & Electricity & HOMER & Total NPC & Off-grid & $\begin{array}{l}\text { PV cell-wind } \\
\text { turbine }\end{array}$ & No & No & No \\
\hline $\begin{array}{l}{[36],} \\
2019\end{array}$ & Quetta & Electricity & $\begin{array}{l}\text { HOMER- } \\
\text { MATLAB }\end{array}$ & Total NPC & Off-grid & $\begin{array}{l}\text { Wind turbine- } \\
\text { battery }\end{array}$ & No & No & No \\
\hline $\begin{array}{l}{[37],} \\
2019\end{array}$ & Faisalabad & Electricity & HOMER & Total NPC & Off-grid & PV cell-battery & No & No & No \\
\hline $\begin{array}{l}{[38],} \\
2019\end{array}$ & Larkana & Electricity & HOMER & $\begin{array}{c}\text { Total NPC- } \\
\text { Emission } \\
\text { analysis }\end{array}$ & On-grid & PV cell-battery & No & No & No \\
\hline $\begin{array}{l}{[39],} \\
2020\end{array}$ & Faisalabad & $\begin{array}{l}\text { Electricity, } \\
\text { heat }\end{array}$ & HOMER & $\begin{array}{l}\text { Total NPC- } \\
\text { Emission } \\
\text { analysis }\end{array}$ & Off-grid & $\begin{array}{c}\text { PV cell-wind } \\
\text { turbine-biogas } \\
\text { generator-diesel } \\
\text { generator }\end{array}$ & Yes & No & No \\
\hline $\begin{array}{l}{[40],} \\
2020\end{array}$ & Sindh & Electricity & HOMER & Total NPC & $\begin{array}{l}\text { On-grid off- } \\
\text { grid }\end{array}$ & $\begin{array}{l}\text { PV cell-wind } \\
\text { turbine-grid }\end{array}$ & No & No & No \\
\hline $\begin{array}{l}\text { Present } \\
\text { work }\end{array}$ & Karachi & $\begin{array}{l}\text { Electricity, } \\
\text { heat and } \\
\text { hydrogen }\end{array}$ & HOMER & $\begin{array}{l}\text { Hydrogen } \\
\text { cost, total } \\
\text { NPC- } \\
\text { emission } \\
\text { analysis }\end{array}$ & Off-grid & $\begin{array}{l}\text { PV cell-wind } \\
\text { turbine-fuel cell- } \\
\text { battery }\end{array}$ & Yes & Yes & Yes \\
\hline
\end{tabular}

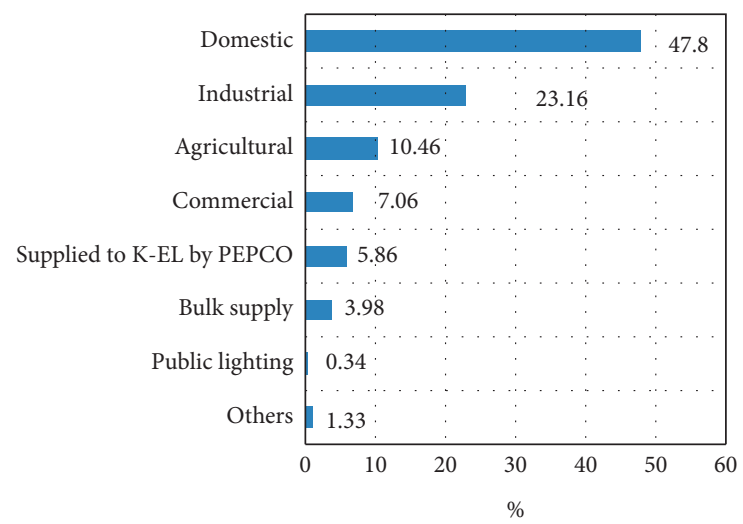

Figure 5: Electric power consumption in different sectors in Pakistan from 2017 to 2018 [8].

$$
\eta_{\mathrm{FC}}=\frac{3.6 P_{\mathrm{FC}}}{\dot{m}_{\text {fuel }} \mathrm{LHV}_{\text {fuel }}},
$$

where $P_{\mathrm{FC}}$ represents the output power in terms of $\mathrm{kW}$, $\mathrm{LHV}_{\text {fuel }}$ is the lower heating value of the fuel in terms of MJ/ $\mathrm{kg}$, and $\dot{m}_{\text {fuel }}$ is the hourly fuel consumption by the fuel cell.

The inverter efficiency is the percentage of the DC power converted to the $\mathrm{AC}$ power by the inverter. The rectifier efficiency is defined as the percentage of the AC power converted to the DC power. Note that HOMER assumes constant inverter and rectifier efficiencies [59].

For modeling a system generating its required hydrogen through electrolysis of the surplus electricity, a hydrogen storage tank should be available to store the hydrogen consumed by the fuel cell. The autonomy of the hydrogen storage tank is defined as the ratio of the energy capacity of hydrogen in the tank to the electric charge [60]:

$$
A_{\text {htank }}=\frac{Y_{\text {htank }} \operatorname{LHV}_{H_{2}}(24(\mathrm{~h} / \mathrm{d}))}{L_{\text {prim.ave }}(3.6(\mathrm{MJ} / \mathrm{kWh}))},
$$

where $Y_{\text {htank }}$ represents the nominal capacity (rated capacity) of the hydrogen tank in terms of $\mathrm{kg}, \mathrm{LHV}_{\mathrm{H}_{2}}$ is the 


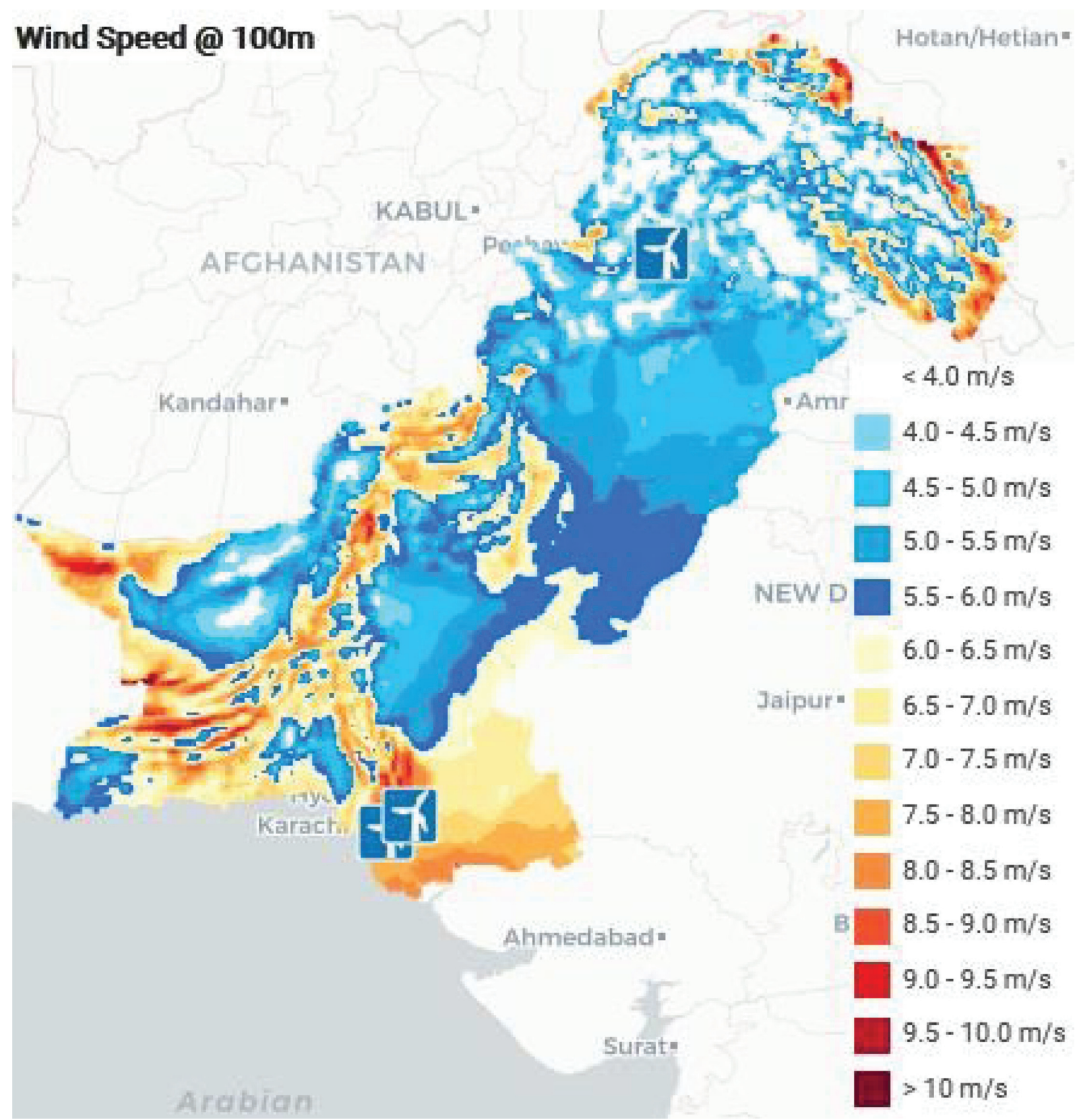

FIGURE 6: Location of large wind power plants in Pakistan [45].

lower heating value of hydrogen $(120 \mathrm{MJ} / \mathrm{kg})$, and $L_{\text {prim,ave }}$ is the average primary load in terms of $\mathrm{kWh} /$ day.

The electrolysis efficiency is defined as the rate of converting electricity into hydrogen, i.e., the energy content of hydrogen based on the higher heating value (HHV) divided by power consumption [61].

The following equation is used in HOMER to calculate the actual annual interest rate $(i)$ from the nominal interest rate $\left(i^{\prime}\right)[62]$ :

$$
i=\frac{i^{\prime}-f}{1+f},
$$

where $f$ is the annual inflation rate. The software assumes an identical inflation rate for all costs. The total NPC is obtained by dividing the total annual cost by the payback period factor, where the payback period factor is calculated as follows [63]:

$$
\mathrm{CRF}=\frac{i(1+i)^{N}}{(1+i)^{N}-1} .
$$

The levelized cost of energy (LCOE) per kWh of the generated power is obtained by dividing the total annual cost by the actual cost of the generated power [64]. The internal rate of return (IRR) is a criterion used in capital budgeting to evaluate the profitability of probable investments. The IRR is a discount rate leading to a zero net present value (NPV) for all cash flows obtained from a particular project and is calculated as follows [65]: 


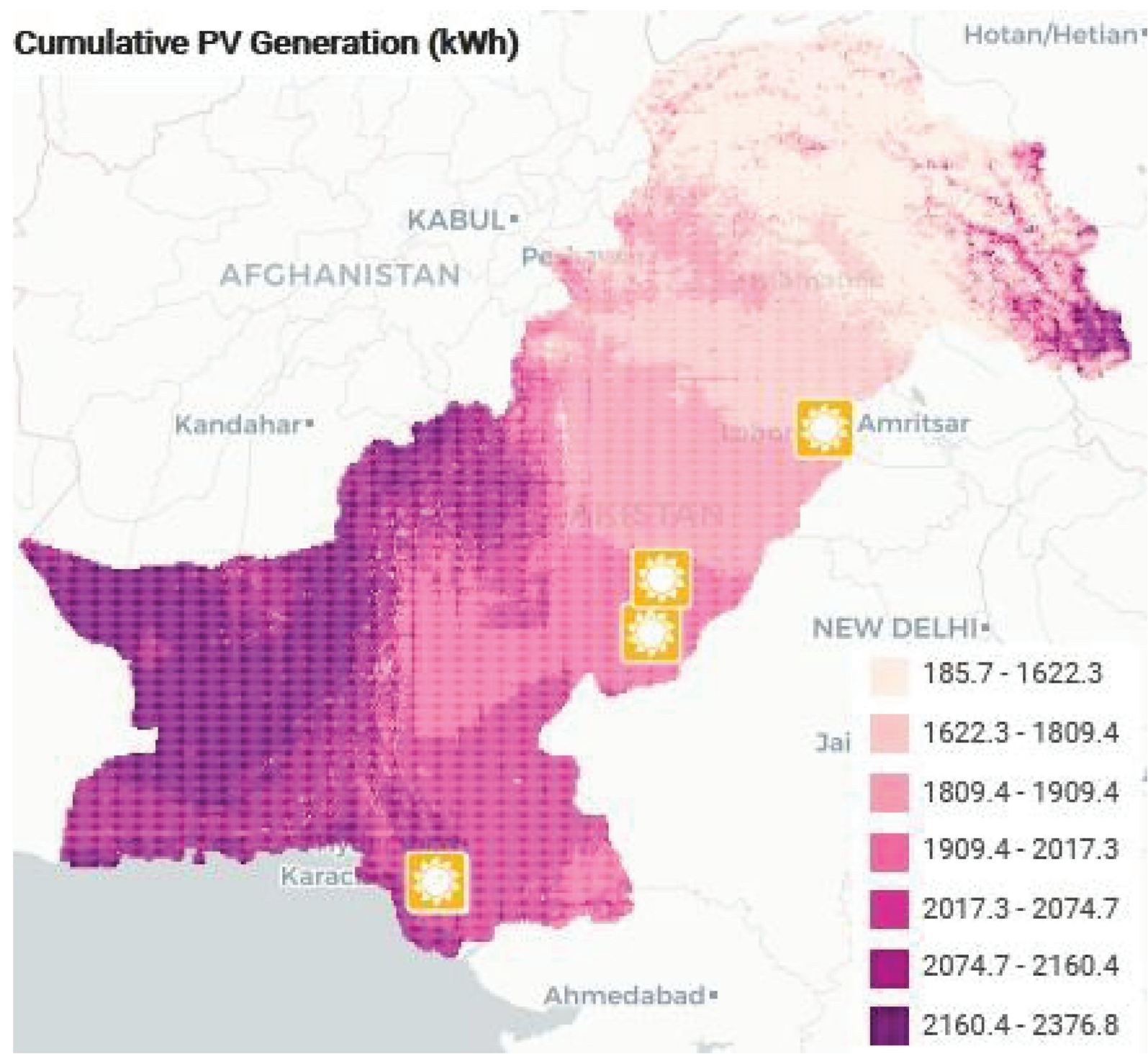

FIGURE 7: Location of large solar power plants in Pakistan [45].

$$
C_{0}=\sum_{t=1}^{T} \frac{C_{t}}{(1+\mathrm{IRR})^{t}},
$$

where $C_{\mathrm{t}}$ is the net inflow in the study period, $C_{0}$ is the total initial investment costs, IRR is the internal rate of return, and $t$ is the number of time steps. A project with a higher IRR is more profitable, and this parameter allows managers to rank projects based on the IRR rather than the NPV.

4.2. Required Data. Figure 8 schematically shows the understudy system. As seen, the most important input data to the software include required power and heat during a $24 \mathrm{~h}$ period as shown in Figures 9(a) [38] and 10(a) [66]. Random variables are used in the software to convert the daily data into annual data. These variables are expressed as hour-tohour and time step-to-time step ones and were, respectively, considered $15 \%$ and $20 \%$ in this study. Applying the random variables, Figures 9(b) and 10(b), respectively, show the electricity and heat required throughout the year.

As shown in Figure 8, a dump load is used in this study to convert the surplus electricity into heat. The dump load or the electric boiler is in fact a resistive heater capable of converting the surplus electricity into heat that cannot be stored in the battery.

The data on solar radiation and wind speed recorded at the understudy station should be used given the use of solar cells and the wind turbine. The average 20-year data were obtained from the NASA website [67] and, respectively, displayed in Figures 11(a) and 11(b). According to Figure 11, the average solar radiation and wind speed at the Karachi Station are $5.34 \mathrm{kWh} / \mathrm{m}^{2}$-day and $3.51 \mathrm{~m} / \mathrm{s}$, respectively.

Given the use of diesel in the boiler, a cost per liter of \$ 0.83 was considered in calculations [68]. To investigate the effect of $\mathrm{CO}_{2}$ emission penalties on the total costs of the system, an emission penalty per ton of $\$ 0,50,100$, and 150 was considered in this study. Furthermore, an actual annual 


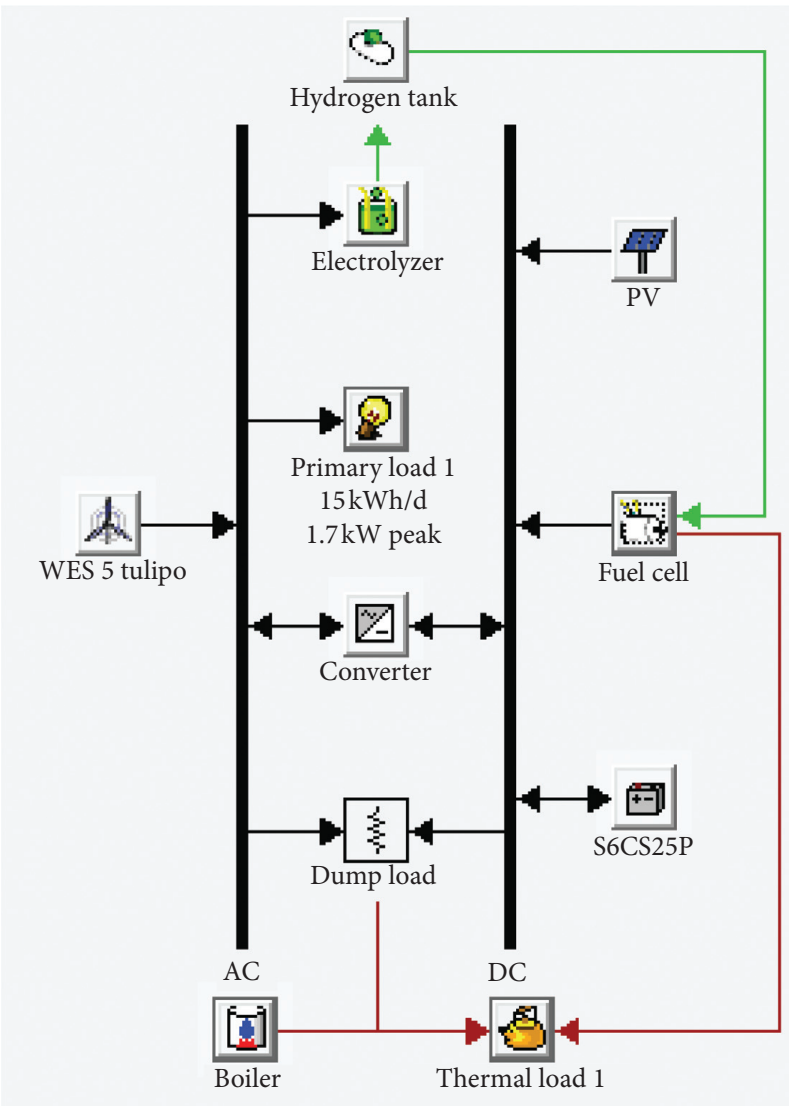

FIGURE 8: Schematic of understudy system.

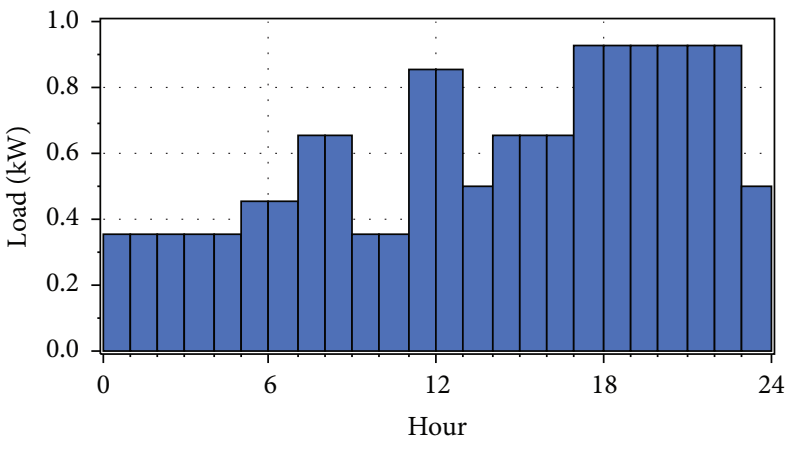

(a)

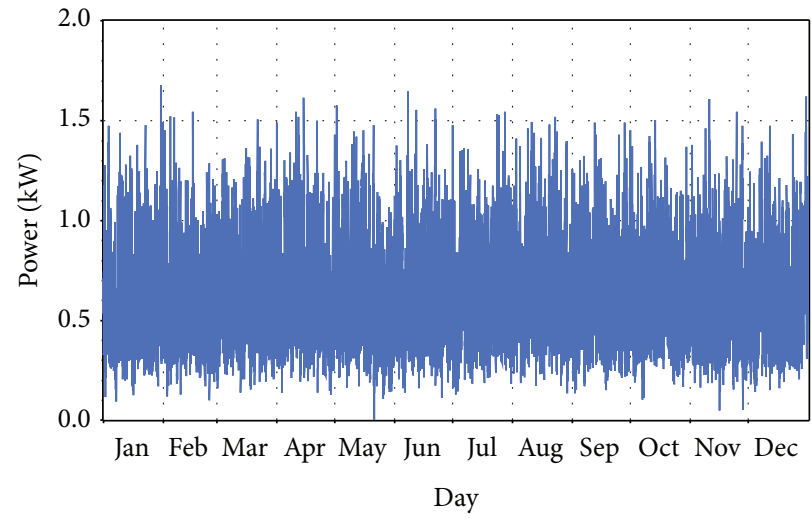

(b)

Figure 9: Electrical load. (a) Daily profile. (b) Yearly profile.

interest rate of 5, 10, 15, and 20\% was considered. Table 2 summarizes the specifications and price of equipment used in the system.

\section{Results}

Table 3 presents the simulation results. As seen, with increasing the annual interest rate, the total NPC decreases whereas the LCOE increases. With increasing the emission penalties, the LCOE decreases, and the performance of the fuel cell and thus the diesel fuel consumption increase.
Moreover, at interest rates of 0 and $5 \%$, the solar cells outperform the wind turbine in terms of energy production and the opposite is true at interest rates of 10 and 15\%. With increasing the emission penalties, the fuel cell is further used and energy production by the fuel cell increases due to the use of the clean hydrogen fuel.

According to the results, the dump load converting the surplus electricity into heat plays a key role in supplying the required thermal energy. An increase in the annual interest rate causes an increase in the LCOE of the generated energy. Consequently, the surplus electricity is infeasible to be 


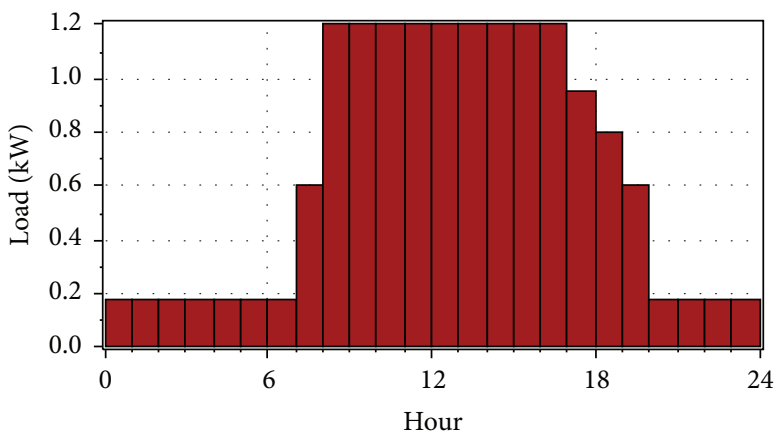

(a)

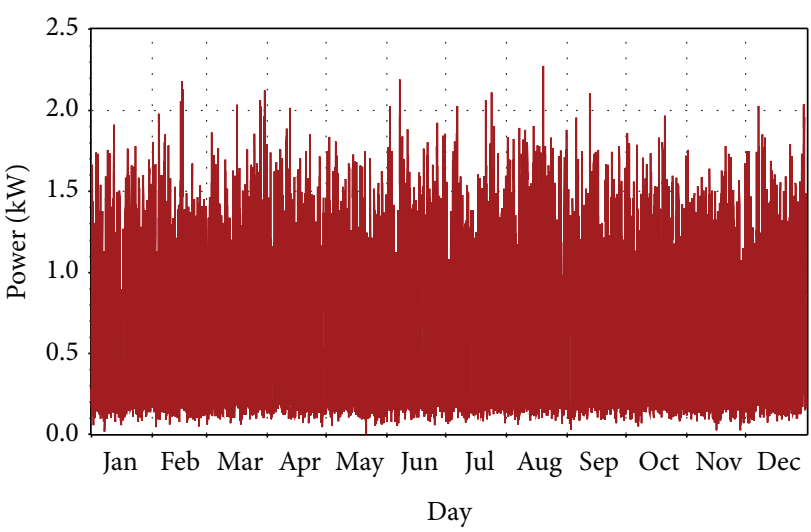

(b)

Figure 10: Thermal load. (a) Daily profile. (b) Yearly profile.

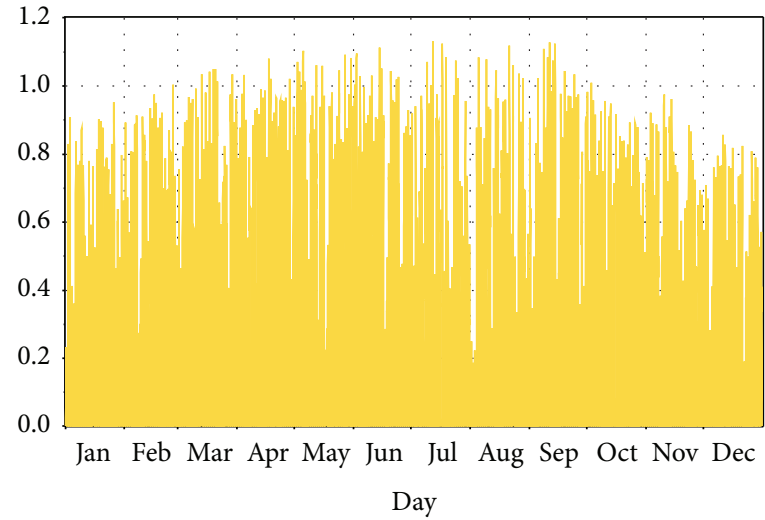

(a)

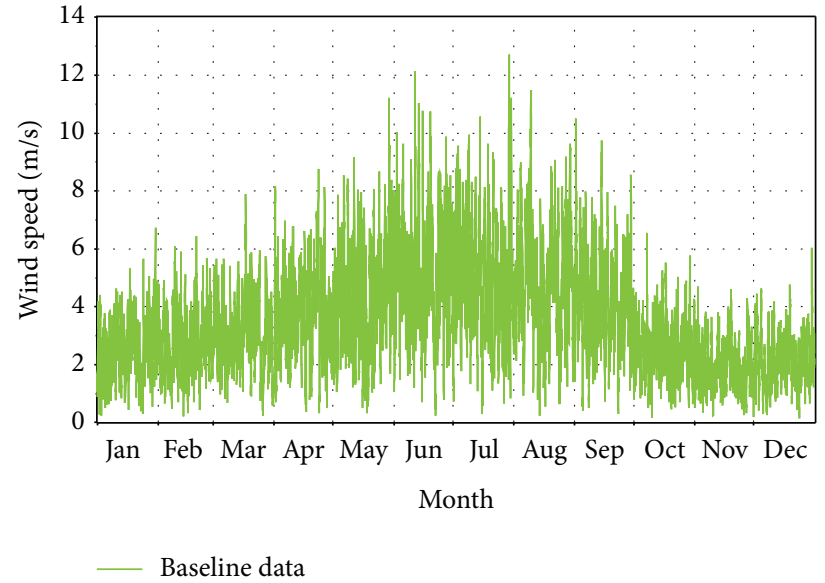

(b)

FiguRE 11: Yearly resources. (a) Global horizontal radiation. (b) Wind speed.

converted into heat by the dump load leading to a lower conversion rate of electricity to heat with increasing the annual interest rate.

The results indicate a negligible hydrogen production rate in different scenarios due to the high costs of electrolysis equipment and the hydrogen storage tank. The low energy production rate by the fuel cell is attributed to the high cost of the fuel cell. Given the negligible $\mathrm{CO}_{2}$ emissions, the understudy region has a great potential to supply the required power and heat from renewable energies. Less energy is produced with an increase in the annual interest rate and thereby an increase in the cost of renewable energy equipment leading to more utilization of the boiler and further diesel fuel consumption. This in turn causes an increase in the $\mathrm{CO}_{2}$ emissions.

It should also be mentioned that, with the increase in penalties for fossil fuel pollutants, the use of these fuels loses its priority. Therefore, the use of fuel cells and, consequently, hydrogen production will be preferred and more widespread. With rising inflation rate, the use of equipment to produce, store, and consume renewable electricity will be less economical. The use of fossil fuels will be more costeffective and, therefore, results in more pollution.

Figure 12 shows the results of the sensitivity analysis of the studied parameters regarding the most economically optimal system. As seen, the solar cell-wind turbine-fuel cell is cost-effective up to an annual interest rate of 8.5-9\% for all emission penalties. The solar cell-wind turbine is, however, more cost-effective at higher interest rates. In a very small range in which the annual interest rate is about $20 \%$ and the emission penalties are close to 0 , the solar cell-based system was identified by the software as the optimal system. It is also seen in Figure 12 that a greater priority is given to hydrogen production at annual interest rates less than $8.5-9 \%$, and higher interest rates rank hydrogen production in the next places in terms of significance.

Figure 13 shows the total NPC for various annual interest rates and emission penalties. The results are consistent with those in Table 3. In other words, the total NPC increases with decreasing the annual interest rate and increasing emission penalties. Figure 13 is also helpful in calculating the LCOE of the generated energy and the total NPC at different 
TABLE 2: Specifications and price of equipment.

\begin{tabular}{|c|c|c|c|c|}
\hline \multirow{2}{*}{ Component } & \multicolumn{3}{|c|}{ Cost $(\$)$} & \multirow{2}{*}{ Specifications } \\
\hline & Capital & Replacement & Operation and maintenance & \\
\hline PV [69] & 2000 & 2000 & 10 & $\begin{array}{l}\text { Lifetime: } 25 \text { years } \\
\text { Derating factor: } 80 \% \\
\text { Slope: } 24.15^{\circ}\end{array}$ \\
\hline Wind turbine [70] & 5000 & 4000 & 50 & $\begin{array}{c}\text { Type: WES } 5 \text { Tulipo } \\
\text { Rated power: } 2.5 \mathrm{~kW} \mathrm{AC} \\
\text { Lifetime: } 25 \text { years } \\
\text { Hub height: } 25 \mathrm{~m} \\
\text { Cut-in speed: } 2 \mathrm{~m} / \mathrm{s}\end{array}$ \\
\hline Battery [70] & 1200 & 1100 & 50 & $\begin{array}{l}\text { Type: Surrette 6CS25P } \\
\text { Lifetime: } 9645 \mathrm{kWh} \\
\text { Lifetime: } 20 \text { years }\end{array}$ \\
\hline Converter [69] & 300 & 300 & 0 & $\begin{array}{l}\text { Inverter efficiency: } 95 \% \\
\text { Rectifier efficiency: } 95 \%\end{array}$ \\
\hline Fuel cell [71] & 3000 & 2500 & 0.02 & $\begin{array}{l}\text { Lifetime: } 40000 \mathrm{~h} \\
\text { Min. load ratio: } 25 \% \\
\text { Efficiency: } 90 \% \\
\text { Heat recovery ratio: } 25 \% \\
\text { Lifetime: } 20 \text { years }\end{array}$ \\
\hline Electrolyzer [71] & 500 & 250 & 10 & $\begin{array}{l}\text { Min. load ratio: } 0 \% \\
\text { Efficiency: } 85 \%\end{array}$ \\
\hline Hydrogen tank [69] & 574 & 574 & 10 & $\begin{array}{c}\text { Lifetime: } 25 \text { years } \\
\text { Initial tank level: } 20 \%\end{array}$ \\
\hline Boiler [72] & - & - & - & $\begin{array}{c}\text { Efficiency: } 85 \% \\
\text { Carbon monoxide } 6.5 \mathrm{~g} / \mathrm{L} \\
\text { Unburned hydrocarbons } 0.72 \mathrm{~g} / \mathrm{L} \\
\text { Particulate matter } 0.49 \mathrm{~g} / \mathrm{L} \\
\text { Fuel sulfur converted to } \mathrm{PM} 2.2 \% \\
\text { Nitrogen oxides } 58 \mathrm{~g} / \mathrm{L}\end{array}$ \\
\hline
\end{tabular}

TABLE 3: Technological-economic-enviromental results of sensitivity analysis.

\begin{tabular}{|c|c|c|c|c|c|c|c|c|c|c|c|c|c|c|}
\hline \multirow{2}{*}{$\begin{array}{l}\text { Interest } \\
\text { rate }(\%)\end{array}$} & \multirow{2}{*}{$\begin{array}{c}\mathrm{CO}_{2} \\
\text { penalty } \\
(\$ / t)\end{array}$} & \multirow{2}{*}{$\begin{array}{c}\text { Total } \\
\text { NPC } \\
(\$)\end{array}$} & \multirow{2}{*}{$\begin{array}{c}\mathrm{LCOE} \\
(\$ / \mathrm{kWh})\end{array}$} & \multirow{2}{*}{$\begin{array}{l}\text { FC } \\
(\mathrm{hr})\end{array}$} & \multirow{2}{*}{$\begin{array}{l}\text { Diesel } \\
(\mathrm{L})\end{array}$} & \multicolumn{3}{|c|}{$\begin{array}{c}\text { Electrical } \\
\text { production }(\mathrm{kWh} / \mathrm{y})\end{array}$} & \multirow{2}{*}{$\begin{array}{c}\text { Excess } \\
\text { electricity } \\
(\%)\end{array}$} & \multicolumn{2}{|c|}{$\begin{array}{l}\text { Thermal } \\
\text { production } \\
(\mathrm{kWh} / \mathrm{y})\end{array}$} & \multirow{2}{*}{$\begin{array}{c}\text { Excess } \\
\text { heat } \\
(\%)\end{array}$} & \multirow{2}{*}{$\begin{array}{c}\mathrm{H}_{2} \\
\text { production } \\
(\mathrm{kg} / \mathrm{y})\end{array}$} & \multirow{2}{*}{$\begin{array}{c}\mathrm{CO}_{2} \\
\text { emission } \\
(\mathrm{kg} / \mathrm{y})\end{array}$} \\
\hline & & & & & & PV & $\begin{array}{l}\text { Wind } \\
\text { turbine }\end{array}$ & $\mathrm{FC}$ & & PV & Boiler & & & \\
\hline \multirow{4}{*}{5} & 0 & 44459 & 0.483 & 844 & 236 & 10121 & 8258 & 502 & 11729 & 104 & 1972 & 8148 & 27.9 & 621 \\
\hline & 50 & 44892 & 0.473 & 840 & 236 & 10121 & 8258 & 504 & 11733 & 103 & 1974 & 8152 & 27.9 & 621 \\
\hline & 100 & 45328 & 0.462 & 835 & 236 & 10121 & 8258 & 510 & 11735 & 103 & 1979 & 8159 & 28.1 & 623 \\
\hline & 150 & 45761 & 0.451 & 830 & 237 & 10121 & 8258 & 512 & 11739 & 102 & 1982 & 8166 & 28 & 624 \\
\hline \multirow{4}{*}{10} & 0 & 40233 & 0.722 & 844 & 236 & 10121 & 8258 & 502 & 11729 & 104 & 1972 & 8148 & 27.9 & 621 \\
\hline & 50 & 40513 & 0.711 & 840 & 236 & 10121 & 8258 & 504 & 11733 & 103 & 1974 & 8152 & 27.9 & 621 \\
\hline & 100 & 40378 & 0.691 & 988 & 338 & 6747 & 8258 & 600 & 8237 & 124 & 2827 & 5530 & 32.6 & 890 \\
\hline & 150 & 40785 & 0.683 & 987 & 338 & 6747 & 8258 & 603 & 8239 & 123 & 2827 & 5533 & 32.6 & 890 \\
\hline \multirow{4}{*}{15} & 0 & 37420 & 0.974 & 262 & 313 & 6747 & 8258 & 193 & 8849 & 29 & 2609 & 5830 & 9.99 & 821 \\
\hline & 50 & 37691 & 0.965 & 269 & 313 & 6747 & 8258 & 203 & 8846 & 30 & 2611 & 5829 & 10.3 & 822 \\
\hline & 100 & 37469 & 0.942 & 988 & 338 & 6747 & 8258 & 600 & 8237 & 124 & 2827 & 5530 & 32.6 & 890 \\
\hline & 150 & 37758 & 0.934 & 987 & 338 & 6747 & 8258 & 603 & 8239 & 123 & 2827 & 5533 & 32.6 & 890 \\
\hline \multirow{4}{*}{20} & 0 & 35738 & 1.242 & 262 & 313 & 6747 & 8258 & 193 & 8849 & 29 & 2609 & 5830 & 9.99 & 821 \\
\hline & 50 & 35945 & 1.233 & 269 & 313 & 6747 & 8258 & 203 & 8846 & 30 & 2611 & 5829 & 10.3 & 822 \\
\hline & 100 & 35795 & 1.211 & 998 & 338 & 6747 & 8258 & 600 & 8237 & 124 & 2827 & 5530 & 32.6 & 890 \\
\hline & 150 & 36017 & 1.202 & 987 & 338 & 6747 & 8258 & 603 & 8239 & 123 & 2827 & 5533 & 32.6 & 890 \\
\hline
\end{tabular}

annual interest rates of 5 to $20 \%$ and emission penalties of $\$ 0$ to 150 per ton of emissions. The same is true for Figure 12.

Given the actual annual interest rate of about $15 \%$ in Pakistan [73] and considering a reasonable price of $\$ 50$ per ton of carbon emissions [74], this scenario is studied in detail below.
Figure 14 shows the approximate current situation of Pakistan. As seen, the wind-solar hybrid system with an LCOE of $\$ 0.923$ is the most optimal system in which $86 \%$ of the generated power is supplied by renewable energies. The second optimal system only includes solar cells and shows a slight increase of about $1.2 \%$ in the LCOE, but the use of 


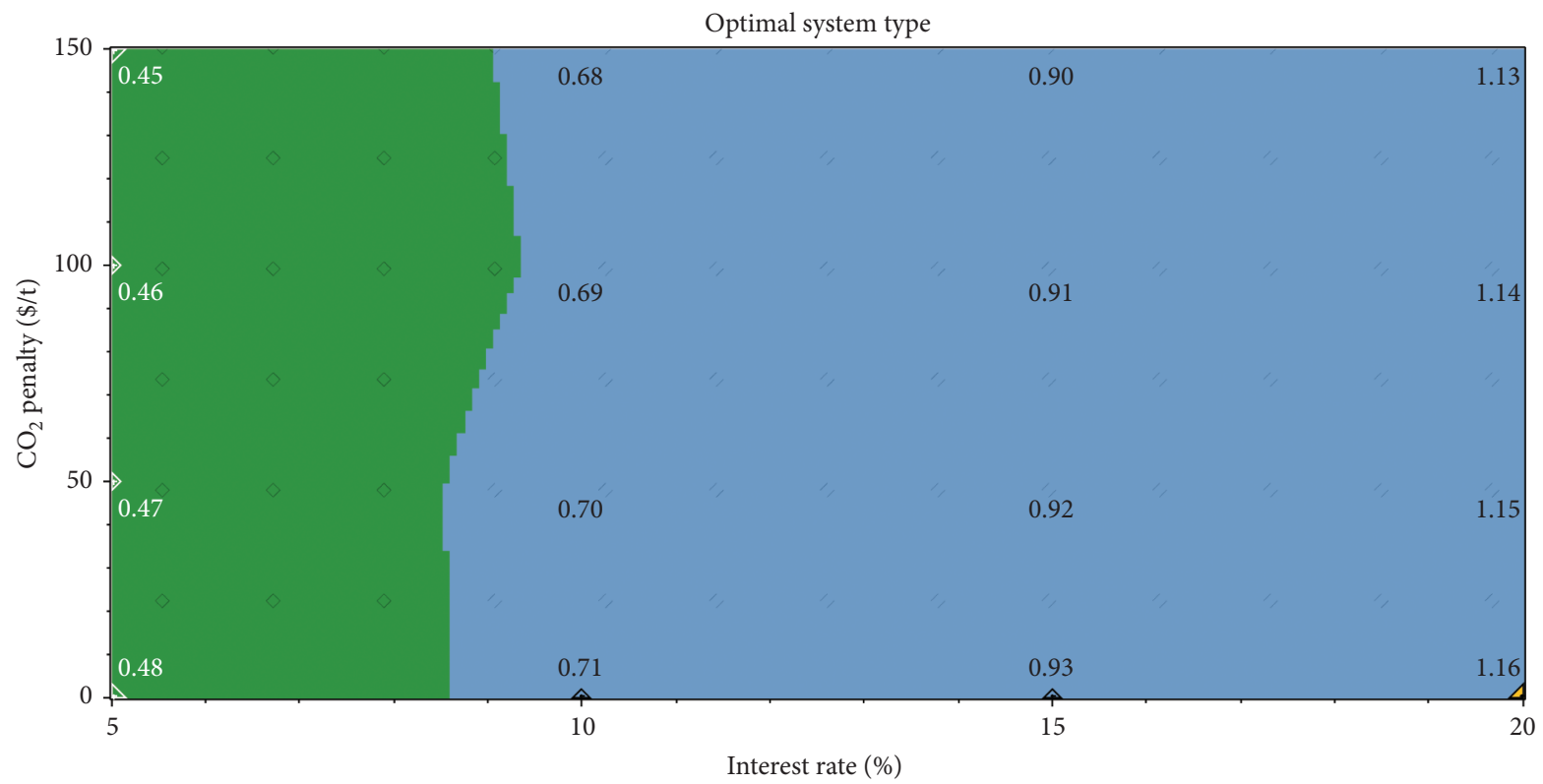

System types

Superimposed

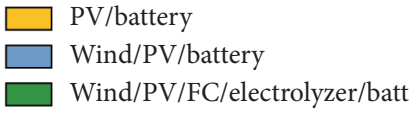

Levelized COE $(\$ / \mathrm{kWh})$

Figure 12: Graph of optimal system type.

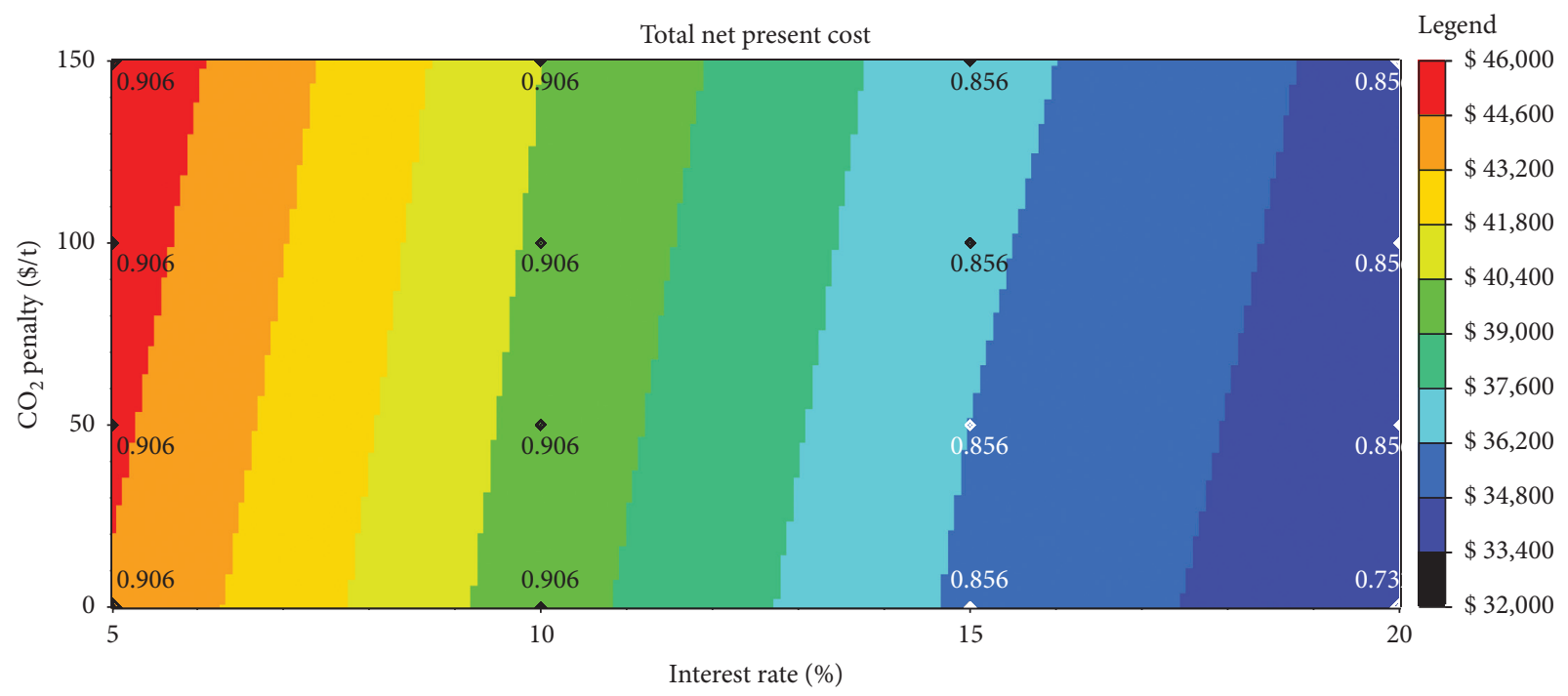

Superimposed

Renewable fraction

FiguRE 13: Surface plot of total NPC.

renewable energies is decreased by $13 \%$ in this system. As shown in Figure 14, hydrogen production by the fuel cell ranks third, and the results are consistent with those in Figure 12. Hydrogen production will increase the LCOE by $4.55 \%$ as compared to the most optimal system (the wind-solar hybrid system). The fourth system lacking batteries is not approved by renewable energy experts. The only advantage of the fourth system over the third one is the production of more hydrogen leading to a $13.37 \%$ increase in the LCOE in comparison with the system in which the battery is used.

Since this study is aimed at cogenerating power, heat, and hydrogen, the third system in Figure 14 was further analyzed. Figure 15 shows the monthly power, heat, and hydrogen generation profiles for the solar cell-wind turbinefuel cell-battery system. 


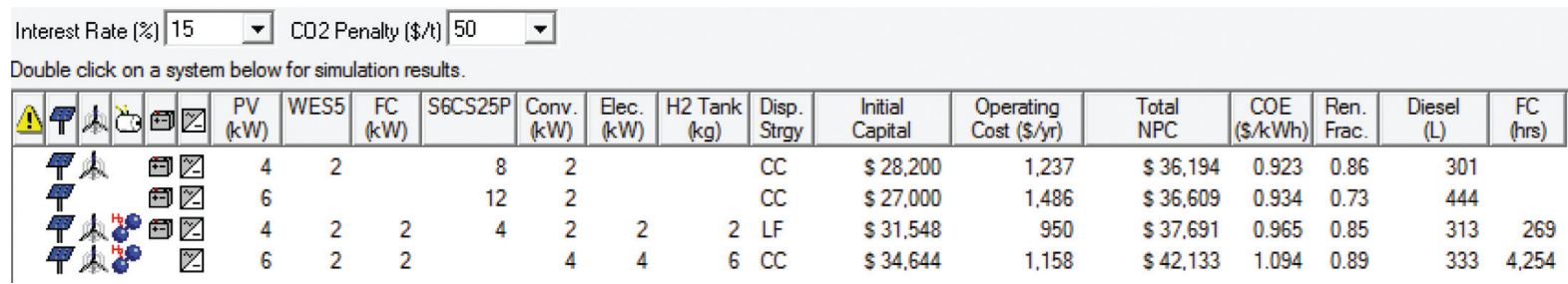

FIGURE 14: Results of simulation for $15 \%$ real interest rate and $\$ 50 / \mathrm{t}$ emission penalty.

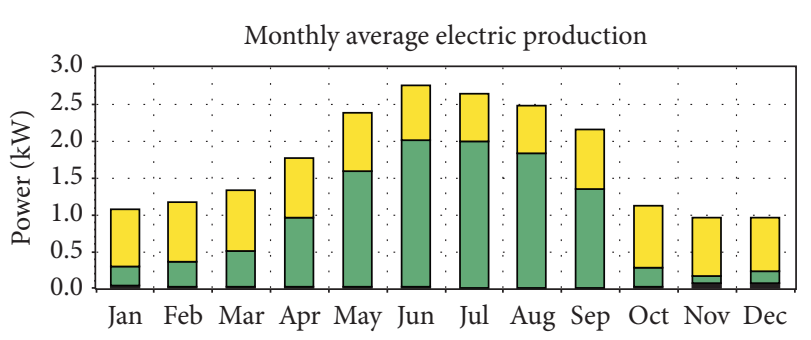

Month

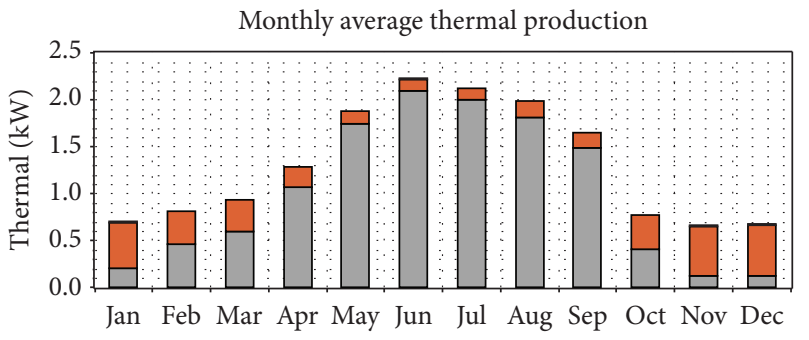

Month

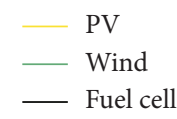

— Fuel cell
B Boiler
Excess electricity

(a)

(b)

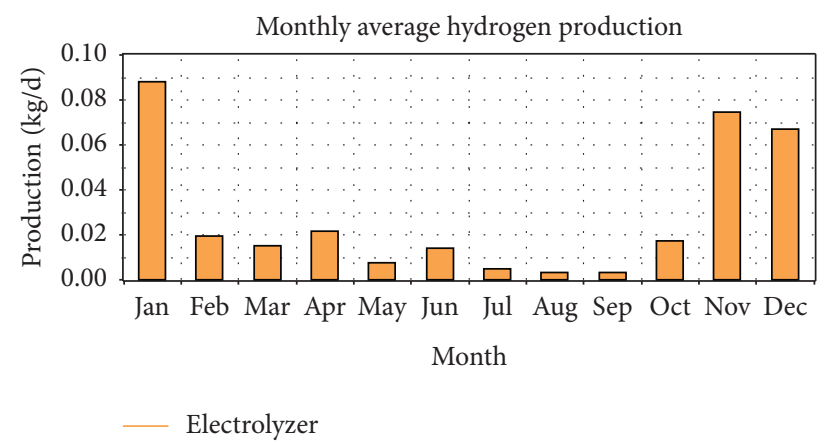

(c)

FIgURE 15: Monthly average production. (a) Electricity. (b) Thermal energy. (c) Hydrogen.

According to the electric power profile, the wind turbine, and solar cells each play a dominant role in power generation in six months. The electric power generation by fuel cell is visible in January, November, and December. As seen in the heat profile, the boiler plays a major role in heat supply in January, November, and December when the electric power generation is low, whereas the dump load plays a major role in this regard in other months by converting the surplus electricity into heat. According to the hydrogen generation profile, a maximum hydrogen generation of about $0.09 \mathrm{~kg} /$ day is observed in January, and the minimum hydrogen generation is seen in August and September.

The notable point implicitly drawn from the results in Figure 15 is that about $8846 \mathrm{kWh}$ surplus electricity is generated annually, which is $58.2 \%$ higher than the required electric power. Moreover, $5829 \mathrm{kWh}$ surplus heat is generated, $103 \%$ more than the required thermal energy. The costs can be significantly reduced by selling the surplus electricity and heat to the national grid or neighbors.
According to Figure 14, despite the higher total NPC, the operating cost of the solar cell-wind turbine-fuel cell-battery system is lower than other systems. To evaluate the payback period, the fuel cell-battery-based system was considered as the base system and compared with other systems during the project lifetime ( 25 years). The results are presented in Figure 16.

Comparing the base system with the wind turbine-solar cell system, the internal rate of return (IRR) equals 9.39\% with a payback period of 11.4 years. In other words, after 11.4 years, the base system will economically outperform the wind turbine-solar cell system. The internal rate of return and the payback period for the base system in comparison with the solar cell only system are $11.7 \%$ and 11 years, respectively. The difference in payback period for an optimal system (base system) compared to solar cell only and wind turbine-solar cell system systems is due to the different prices of equipment purchase, operating and maintenance, and operation of these systems. 

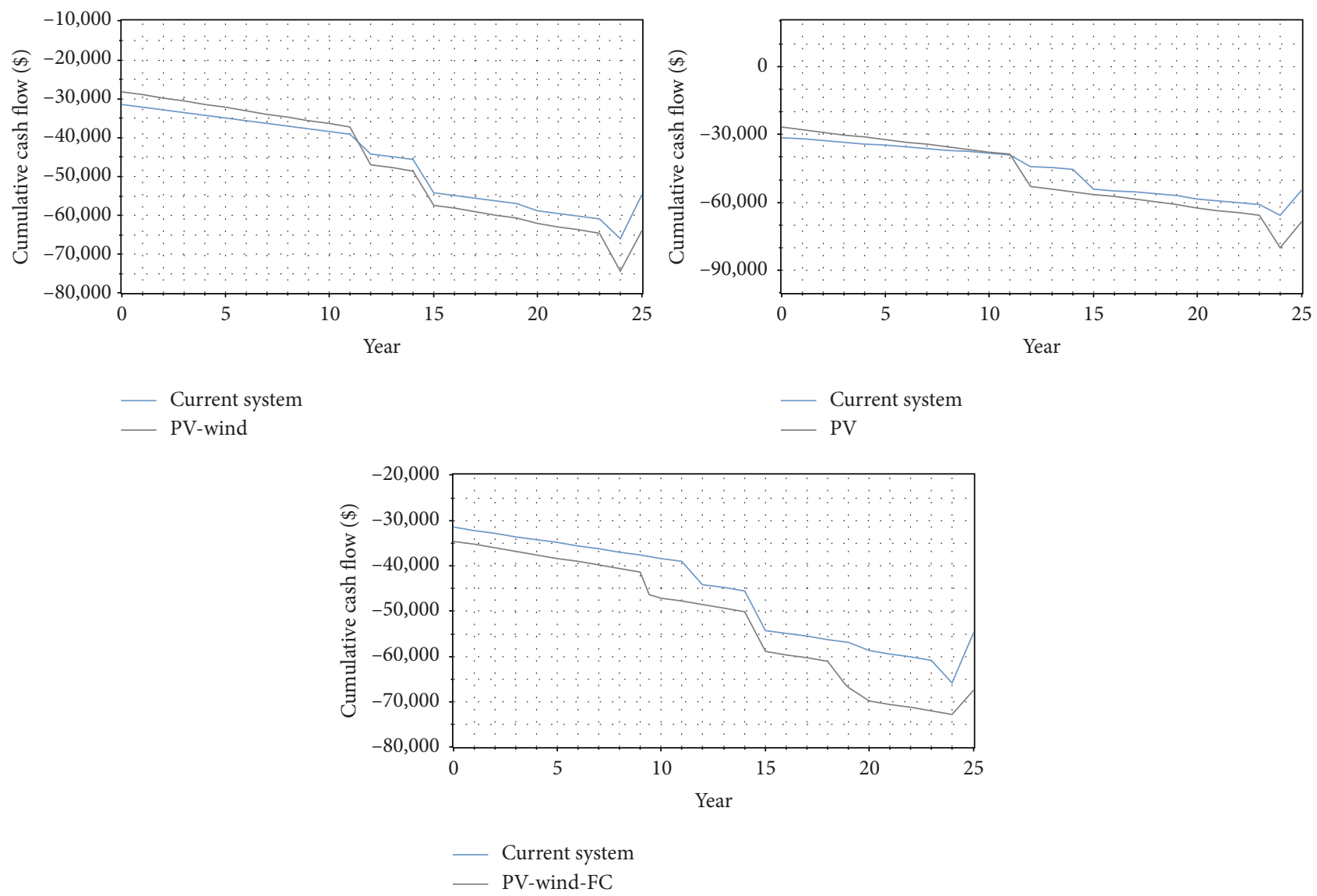

Figure 16: Current system compared to base case.

Comparing the base system with the system including the fuel cell without a battery, it can be seen that there are no payback period and internal rate of return and the base system outperforms other systems throughout the 25-year lifetime of the project. This highlights the need for the use of a battery as a backup.

\section{Conclusion}

About 51 million Pakistanis do not have access to Pakistan's national grid, and more than 144 million people do have unreliable access to the national grid [75]. Therefore, the Government of Pakistan is aware of the necessity for improving the current energy situation through policies and renewable energy projects. Considering undeveloped renewable energies in Pakistan, there is a serious need for the use of distributed generation systems based on renewable energies. Accordingly, for the first time in this study, cogeneration of power, heat, and hydrogen in a residential building in Karachi was investigated using the average 20year data on wind speed and solar radiation extracted from the NASA website and updated costs of renewable energy equipment and fossil fuels. Given the variable annual interest rate and to study the effect of emission penalties on the LCOE of the generated energy and hydrogen, a sensitivity analysis was performed on these parameters. For the first time, the surplus renewable electric power was converted into heat. The main results are summarized below:

(i) The total NPC decreased but the LCOE increased with increasing the annual interest rate

(ii) The LCOE and utilization of fuel cells increased with increasing the emission penalties

(iii) Solar energy outperformed wind energy at interest rates less than $10 \%$

(iv) The dump load plays a significant role in supplying the required heat

(v) There is a low potential for generating renewable hydrogen in Karachi

(vi) There is a high potential for cogeneration of renewable power and heat in Karachi

(vii) Hydrogen generation ranked first economically at interest rates less than $9 \%$

(viii) The solar cell-battery system ranked first at interest rates above $20 \%$ and emission penalties of zero

(ix) The surplus renewable electricity and renewable heat in Karachi were, respectively, 85.2\% and 103\%

(x) The most optimal system for hydrogen generation relative to the wind-solar and solar-only systems, respectively, showed a payback period of 11.4 and 11 years 


\section{Data Availability}

All data used to support the findings of this study are included within the article.

\section{Conflicts of Interest}

The authors declare that they have no conflicts of interest.

\section{References}

[1] M. Usman, A. M. Malik, A. Mahmood, A. Kousar, and K. Sabeel, "HOMER analysis for integrating solar energy in off-grid and on-grid SCO telecommunication sites," in Proceedings of the 1st Global Power, Energy and Communication Conference (GPECOM), pp. 270-275, Nevsehir, Turkey, June 2019.

[2] M. Kamran, M. R. Fazal, and M. Mudassar, "Towards empowerment of the renewable energy sector in Pakistan for sustainable energy evolution: SWOT analysis," Renewable Energy, vol. 146, pp. 543-558, 2020.

[3] S. R. Khandker, D. F. Barnes, and H. A. Samad, "Are the energy poor also income poor? Evidence from India," Energy Policy, vol. 47, pp. 1-12, 2012.

[4] M. Kamran, "Current status and future success of renewable energy in Pakistan," Renewable and Sustainable Energy Reviews, vol. 82, pp. 609-617, 2018.

[5] T. Aized, M. Shahid, A. A. Bhatti, M. Saleem, and G. Anandarajah, "Energy security and renewable energy policy analysis of Pakistan," Renewable and Sustainable Energy Reviews, vol. 84, pp. 155-169, 2018.

[6] A. Rehman, A. Rauf, M. Ahmad, A. A. Chandio, and Z. Deyuan, "The effect of carbon dioxide emission and the consumption of electrical energy, fossil fuel energy, and renewable energy, on economic performance: evidence from Pakistan," Environmental Science and Pollution Research, vol. 26, pp. 21760-21773, 2019.

[7] F. Ali, Y. Jiang, and K. Khan, "Feasibility analysis of renewable based hybrid energy system for the remote community in Pakistan," in Proceedings of the 2017 IEEE International Conference on Industrial Engineering and Engineering Management (IEEM), pp. 344-348, Singapore, December 2017.

[8] S. A. A. Shah and Y. A. Solangi, "A sustainable solution for electricity crisis in Pakistan: opportunities, barriers, and policy implications for $100 \%$ renewable energy," Environmental Science and Pollution Research International, vol. 26, no. 29, pp. 29687-29703, 2019.

[9] M. Y. Raza, M. Wasim, and M. S. Sarwar, "Development of renewable energy technologies in rural areas of Pakistan," Energy Sources, Part A: Recovery, Utilization, and Environmental Effects, vol. 42, no. 6, pp. 1-21, 2020.

[10] NTDC, Power System Statistics Pakistan 2017-18, NTDC, Lahore, Pakistan, 2018, http://www.ntdc.com.pk/ntdc/public/ uploads/services/planning/power\%20system\%20statistics/pss $\% 2042$ nd\%20edition.pdf.

[11] S. A. A. Shah, Y. A. Solangi, and M. Ikram, "Analysis of barriers to the adoption of cleaner energy technologies in Pakistan using modified Delphi and fuzzy analytical hierarchy process," Journal of Cleaner Production, vol. 235, pp. 10371050, 2019.

[12] M. A. Sheikh, "Energy and renewable energy scenario of Pakistan," Renewable and Sustainable Energy Reviews, vol. 14, no. 1, pp. 354-363, 2010.
[13] M. Luqman, N. Ahmad, and K. Bakhsh, "Nuclear energy, renewable energy and economic growth in Pakistan: evidence from non-linear autoregressive distributed lag model," Renewable Energy, vol. 139, pp. 1299-1309, 2019.

[14] Global Wind Atlas, 2020, https://globalwindatlas.info/area/ Pakistan.

[15] M. K. Farooq and S. Kumar, "An assessment of renewable energy potential for electricity generation in Pakistan," Renewable and Sustainable Energy Reviews, vol. 20, pp. 240-254, 2013.

[16] S. Siddique and R. Wazir, "A review of the wind power developments in Pakistan," Renewable and Sustainable Energy Reviews, vol. 57, pp. 351-361, 2016.

[17] M. Jahangiri, A. Haghani, A. Alidadi Shamsabadi, A. Mostafaeipour, and L. M. Pomares, "Feasibility study on the provision of electricity and hydrogen for domestic purposes in the south of Iran using grid-connected renewable energy plants," Energy Strategy Reviews, vol. 23, pp. 23-32, 2019.

[18] K. H. Solangi, M. R. Islam, R. Saidur, N. A. Rahim, and H. Fayaz, "A review on global solar energy policy," Renewable and Sustainable Energy Reviews, vol. 15, no. 4, pp. 2149-2163, 2011.

[19] Global Horizontal Irradiation, Solar Resource Maps of Pakistan, Solargis, Bratislava, Slovakia, https://solargis. com/maps-and-gis-data/download/pakistan, 2020.

[20] M. A. Chaudhry, R. Raza, and S. A. Hayat, "Renewable energy technologies in Pakistan: prospects and challenges," Renewable and Sustainable Energy Reviews, vol. 13, no. 6-7, pp. 1657-1662, 2009.

[21] A. W. Bhutto, A. A. Bazmi, and G. Zahedi, "Greener energy: issues and challenges for Pakistan-solar energy prospective," Renewable and Sustainable Energy Reviews, vol. 16, no. 5, pp. 2762-2780, 2012.

[22] A. Ghafoor, T. U. Rehman, A. Munir, M. Ahmad, and M. Iqbal, "Current status and overview of renewable energy potential in Pakistan for continuous energy sustainability," Renewable and Sustainable Energy Reviews, vol. 60, pp. 1332-1342, 2016.

[23] M. Kamran, M. Mudassar, S. R. Ahmed et al., "Socioeconomic acceptance for stand-alone solar PV systems: survey evidence from southern Punjab, Pakistan," International Journal of Renewable Energy Research (IJRER), vol. 9, no. 1, pp. 301-308, 2019.

[24] A. Ashfaq and A. Ianakiev, "Features of fully integrated renewable energy atlas for Pakistan; wind, solar and cooling," Renewable and Sustainable Energy Reviews, vol. 97, pp. 14-27, 2018.

[25] L. Xu, S. A. A. Shah, H. Zameer, and Y. A. Solangi, "Evaluating renewable energy sources for implementing the hydrogen economy in Pakistan: a two-stage fuzzy MCDM approach," Environmental Science and Pollution Research, vol. 26, no. 32, pp. 33202-33215, 2019.

[26] W. Iqbal, H. Yumei, Q. Abbas et al., "Assessment of wind energy potential for the production of renewable hydrogen in Sindh province of Pakistan," Processes, vol. 7, no. 4, p. 196, 2019.

[27] S. E. Hosseini and M. A. Wahid, "Hydrogen production from renewable and sustainable energy resources: promising green energy carrier for clean development," Renewable and Sustainable Energy Reviews, vol. 57, pp. 850-866, 2016.

[28] P. Nikolaidis and A. Poullikkas, "A comparative overview of hydrogen production processes," Renewable and Sustainable Energy Reviews, vol. 67, pp. 597-611, 2017. 
[29] S. Hussain Siyal, M. Hopper, A. Lefvert et al., "GIS-based preliminary wind-hydrogen energy assessment: a case study for Pakistan," in Proceedings of the EGU General Assembly Conference Abstracts, p. 15638, Vienna, Austria, April 2017.

[30] M. K. Shahzad, A. Zahid, T. Ur Rashid, M. A. Rehan, M. Ali, and M. Ahmad, "Techno-economic feasibility analysis of a solar-biomass off grid system for the electrification of remote rural areas in Pakistan using HOMER software," Renewable Energy, vol. 106, pp. 264-273, 2017.

[31] A. Khan and R. Khan, "Cost optimization of hybrid microgrid using solar PV, fuel cell and diesel generator in HOMER," in Proceedings of the 2018 2nd International Conference on Energy Conservation and Efficiency (ICECE), pp. 14-18, Lahore, Pakistan, October 2018.

[32] J. Ahmad, M. Imran, A. Khalid et al., "Techno economic analysis of a wind-photovoltaic-biomass hybrid renewable energy system for rural electrification: a case study of Kallar Kahar," Energy, vol. 148, pp. 208-234, 2018.

[33] M. Mohsin, A. K. Rasheed, and R. Saidur, "Economic viability and production capacity of wind generated renewable hydrogen," International Journal of Hydrogen Energy, vol. 43, no. 5, pp. 2621-2630, 2018.

[34] M. Kamran, R. Asghar, M. Mudassar et al., "Designing and optimization of stand-alone hybrid renewable energy system for rural areas of Punjab, Pakistan," International Journal of Renewable Energy Research, vol. 8, no. 4, pp. 2385-2397, 2018.

[35] M. A. Khan, M. S. Aziz, A. Khan, K. Zeb, W. Uddin, and M. Ishfaq, "An optimized off-gird renewable AC/DC microgrid for remote communities of Pakistan," in Proceedings of the 2019 International Conference on Electrical, Communication, and Computer Engineering (ICECCE), pp. 1-6, IEEE, Swat, Pakistan, July 2019.

[36] H. U. R. Habib, S. Wang, M. R. Elkadeem, and M. F. Elmorshedy, "Design optimization and model predictive control of a standalone hybrid renewable energy system: a case study on a small residential load in Pakistan," IEEE Access, vol. 7, pp. 117369-117390, 2019.

[37] A. Iqbal and M. T. Iqbal, "Design and analysis of a stand-alone PV system for a rural house in Pakistan," International Journal of Photoenergy, vol. 2019, Article ID 4967148, 8 pages, 2019.

[38] S. U. Rehman, S. Rehman, M. Shoaib, and I. A. Siddiqui, "Feasibility study of a grid-tied photovoltaic system for household in Pakistan: considering an unreliable electric grid," Environmental Progress \& Sustainable Energy, vol. 38, no. 3, pp. 1-8, 2019.

[39] O. A. Memon, A. M. Soomro, M. Kumar, and M. Farhan, "Implementation of microgrid with integration of hybrid renewable sources using different backup techniques," Indian Journal of Science and Technology, vol. 13, no. 33, pp. 34573466, 2020.

[40] Z. Javid, K. J. Li, R. Ul Hassan, and J. Chen, "Hybridmicrogrid planning, sizing and optimization for an industrial demand in Pakistan," Tehnicki Vjesnik, vol. 27, no. 3, pp. 781-792, 2020.

[41] M. Jahangiri, A. Haghani, S. Heidarian, A. Alidadi Shamsabadi, and L. M. Pomares, "Electrification of a tourist village using hybrid renewable energy systems, Sarakhiyeh in Iran," Journal of Solar Energy Research, vol. 3, no. 3, pp. 201-211, 2018.

[42] I. Ulfat, F. Javed, F. A. Abbasi et al., "Estimation of solar energy potential for Islamabad, Pakistan," Energy Procedia, vol. 18, pp. 1496-1500, 2012.
[43] M. H. Baloch, J. Wang, G. S. Kaloi, A. A. Memon, A. S. Larik, and P. Sharma, "Techno-economic analysis of power generation from a potential wind corridor of Pakistan: an overview," Environmental Progress \& Sustainable Energy, vol. 38, no. 2, pp. 706-720, 2019.

[44] S. H. Shami, J. Ahmad, R. Zafar, M. Haris, and S. Bashir, "Evaluating wind energy potential in Pakistan's three provinces, with proposal for integration into national power grid," Renewable and Sustainable Energy Reviews, vol. 53, pp. 408421, 2016.

[45] Maps, National Renewable Energy Laboratory (NREL), https://maps.nrel.gov/rede-pakistan/?aL=0i05w8\%255Bv\% 255D\%3Dt\%269y6tYL\%255Bv\%255D\%3Dt\%269y6tYL\% $255 \mathrm{Bd} \% 255 \mathrm{D} \% 3 \mathrm{D} 1 \& \mathrm{bL}=$ clight $\& \mathrm{cE}=0 \& \mathrm{lR}=0 \& \mathrm{mC}=31$. $16580958786196 \% 2 \mathrm{C} 77.82714843749999 \& z L=5$.

[46] U. Zafar, T. Ur Rashid, A. A. Khosa, M. S. Khalil, and M. Rashid, "An overview of implemented renewable energy policy of Pakistan," Renewable and Sustainable Energy Reviews, vol. 82, pp. 654-665, 2018.

[47] M. Jahangiri, R. Ghaderi, A. Haghani, and O. Nematollahi, "Finding the best locations for establishment of solar-wind power stations in middle-east using GIS: a review," Renewable and Sustainable Energy Reviews, vol. 66, pp. 38-52, 2016.

[48] M. Jahangiri, O. Nematollahi, E. Heidari Sooreshjani, and A. Heidari Sooreshjani, "Investigating the current state of solar energy use in countries with strong radiation potential in asia using GIS software, a review," Journal of Solar Energy Research, vol. 5, no. 3, pp. 477-497, 2020.

[49] R. Kalbasi, M. Jahangiri, A. Nariman, and M. Yari, "Optimal design and parametric assessment of grid-connected solar power plants in Iran, a review," Journal of Solar Energy Research, vol. 4, no. 2, pp. 142-162, 2019.

[50] O. Nematollahi, P. Alamdari, M. Jahangiri, A. Sedaghat, and A. A. Alemrajabi, "A techno-economical assessment of solar/ wind resources and hydrogen production: a case study with GIS maps," Energy, vol. 175, pp. 914-930, 2019.

[51] A. Mostafaeipour, M. Rezaei, M. Jahangiri, and M. Qolipour, "Feasibility analysis of a new tree-shaped wind turbine for urban application: a case study," Energy \& Environment, vol. 31, no. 7, pp. 1230-1256, 2020.

[52] P. Alamdari, O. Nematollahi, and M. Jahangiri, "Feasibility study of wind energy for generate electricity in Province of Sistan and Baluchistan, case study: Nosrat Abad," in Proceedings of the 3rd International Scientific Conference of Iranian Students, pp. 1-9, Minsk, Belarus, 2012.

[53] M. Jahangiri, A. Hajji Malayeri, A. Sedaghat, and E. Aghaei, "Investigating wind potential for clean energy production in Khorasan Razavi province, case study: Jangal station," in Proceedings of the 1st Specialty Conference of the Wind and Sun, pp. 1-9, Tehran, Iran, 2012.

[54] A. S. Aziz, M. F. N. Tajuddin, M. R. Adzman, and M. A. Ramli, "Impacts of albedo and atmospheric conditions on the efficiency of solar energy: a case study in temperate climate of Choman, Iraq," Environment, Development and Sustainability, vol. 23, pp. 989-1018, 2021.

[55] M. Jahangiri, A. Khosravi, H. A. Raiesi, and A. Mostafaeipour, "Analysis of standalone PV-based hybrid systems for power generation in rural area," in Proceedings of the International Conference on Fundamental Research in Electrical Engineering, pp. 1-2, Tehran, Iran, 2017.

[56] S. Vahdatpour, S. Behzadfar, L. Siampour, E. Veisi, and M. Jahangiri, "Evaluation of off-grid hybrid renewable systems in the four climate regions of Iran," Journal of Renewable Energy and Environment, vol. 4, no. 1, pp. 61-70, 2018. 
[57] M. Moein, S. Pahlavan, M. Jahangiri, and A. Alidadi Shamsabadi, "Finding the minimum distance from the national electricity grid for the cost-effective use of diesel generatorbased hybrid renewable systems in Iran," Journal of Renewable Energy and Environment, vol. 5, no. 1, pp. 8-22, 2018.

[58] A. R. Ariae, M. Jahangiri, M. H. Fakhr, and A. A. Shamsabadi, "Simulation of biogas utilization effect on the economic efficiency and greenhouse gas emission: a case study in Isfahan, Iran," International Journal of Renewable Energy Development, vol. 8, no. 2, pp. 149-160, 2019.

[59] M. Jahangiri, A. Haghani, A. Mostafaeipour, A. Khosravi, and H. A. Raeisi, "Assessment of solar-wind power plants in Afghanistan: a review," Renewable and Sustainable Energy Reviews, vol. 99, pp. 169-190, 2019.

[60] M. Jahangiri, M. H. Soulouknga, F. K. Bardei et al., “Technoecono-environmental optimal operation of grid-wind-solar electricity generation with hydrogen storage system for domestic scale, case study in Chad," International Journal of Hydrogen Energy, vol. 44, no. 54, pp. 28613-28628, 2019.

[61] M. Mostafaeipour, O. Nematollahi, A. Haghani, H. A. Raiesi, and A. Alidadi Shamsabadi, "An optimization of energy cost of clean hybrid solar-wind power plants in Iran," International Journal of Green Energy, vol. 16, no. 15, pp. 1422-1435, 2019.

[62] M. Jahangiri, R. A. Rizi, and A. A. Shamsabadi, "Feasibility study on simultaneous generation of electricity and heat using renewable energies in Zarrin Shahr, Iran," Sustainable Cities and Society, vol. 38, pp. 647-661, 2018.

[63] S. Ebrahimi, M. Jahangiri, H. A. Raiesi, and A. R. Ariae, "Optimal planning of on-grid hybrid microgrid for remote Island using HOMER software, Kish in Iran," International Journal of Energetica, vol. 3, no. 2, pp. 13-21, 2018.

[64] M. Jahangiri, O. Nematollahi, A. Sedaghat, and M. Saghafian, "Techno-economical assessment of renewable energies integrated with fuel cell for off grid electrification: a case study for developing countries," Journal of Renewable and Sustainable Energy, vol. 7, no. 2, Article ID 023123, 2015.

[65] Internal Rate of Return-IRR, https://www.investopedia.com/ terms/i/irr.asp.

[66] A. Waqar, M. Shahbaz Tanveer, J. Ahmad, M. Aamir, M. Yaqoob, and F. Anwar, "Multi-objective analysis of a CHP plant integrated microgrid in Pakistan," Energies, vol. 10, no. 10, p. 1625, 2017.

[67] R. E. Ganoe, P. W. Stackhouse, and R. J. DeYoung, RETScreen $^{\circledR}$ Plus Software Tutorial, pp. 3-27, National Aeronautics and Space Administration (NASA), Washington, DC, USA, 2017.

[68] Trading Economics, Interest Rate, Asia, https:// tradingeconomics.com/country-list/interest-rate? continent $=$ asia.

[69] M. R. Akhtari and M. Baneshi, "Techno-economic assessment and optimization of a hybrid renewable co-supply of electricity, heat and hydrogen system to enhance performance by recovering excess electricity for a large energy consumer," Energy Conversion and Management, vol. 188, pp. 131-141, 2019.

[70] T. Abdali, S. Pahlavan, M. Jahangiri, A. Alidadi Shamsabadi, and F. Sayadi, "Techno-econo-environmental study on the use of domestic-scale wind turbines in Iran," Energy Equipment and Systems, vol. 7, no. 4, pp. 317-338, 2019.

[71] H. Rezk, E. T. Sayed, M. Al-Dhaifallah et al., "Fuel cell as an effective energy storage in reverse osmosis desalination plant powered by photovoltaic system," Energy, vol. 175, pp. 423433, 2019.
[72] S. Pahlavan, M. Jahangiri, A. Alidadi Shamsabadi, and A. Rahimi Ariae, "Assessment of PV-based CHP system: the effect of heat recovery factor and fuel type," Journal of Energy Management and Technology, vol. 3, no. 1, pp. 40-47, 2019.

[73] Interest Rate, ASIA, Trading Economics, https:// tradingeconomics.com/country-list/interest-rate? continent $=$ asia.

[74] Putting a Price on Pollution, International Monetary Fund, https:/www.imf.org/external/pubs/ft/fandd/2019/12/thecase-for-carbon-taxation-and-putting-a-price-on-pollutionparry.htm.

[75] Pakistan Energy Situation, Energypedia, https://energypedia. info/wiki/Pakistan_Energy_Situation. 